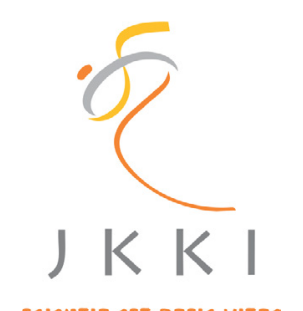

Jurnal Kedokteran dan Kesehatan Indonesia

Indonesian Journal of Medicine and Health

Journal homepage : www.journal.uii.ac.id/index.php/JKKI

\title{
The effect of the onset of seizure on clock drawing test score of epilepsy patients
}

Baiq Kania Kartika Yaksa*1, Herpan Syafii Harahap², Emmy Amalia ${ }^{3}$, Yanna Indrayana ${ }^{4}$

${ }^{1}$ Student of Medical Doctor, Universitas Mataram, Mataram, Indonesia

${ }^{2}$ Departement of Neurology, Universitas Mataram, Mataram, Indonesia

${ }^{3}$ Departement of Psychiatry, Universitas Mataram, Mataram, Indonesia

${ }^{4}$ Departement of Cardiology, Universitas Mataram, Mataram, Indonesia

Original Article

\begin{tabular}{l}
\hline \\
\hline ARTICLE INF O \\
\hline Keywords: \\
The onset of seizure, \\
epilepsy, \\
CDT score, \\
cognitive function \\
*Corresponding author: \\
kaniakartikayaksa@gmail.com \\
\hline D0I : 10.20885/JKKI.Vol9.Iss2.art6 \\
\hline History: \\
Received: February 6, 2018 \\
Accepted: June 29, 2018 \\
Online: August 30, 2018 \\
\hline Copyright @2018 Authors. \\
This is an open access article \\
distributed under the terms \\
of the Creative Commons At- \\
tribution-NonCommercial 4.0 \\
International Licence (http:// \\
creativecommons.org/licences/ \\
by-nc/4.0/).
\end{tabular}

\section{ABSTRACT}

Background: Epilepsy is one of the causing factors of cognitive impairment which affects the patient's quality of life. The most critical risk factor for cognitive impairment in epilepsy patients is the onset of seizure. Performing detection of cognitive impairment in those patients is crucial. Clock Drawing Test (CDT) is a validated instrument for the detection of cognitive impairment in epilepsy patients.

Objective: This study was aimed to investigate the effect of the onset of seizure on CDT score in epilepsy patients.

Methods: This study was a cross-sectional study involving 64 epilepsy patients of Mutiara Sukma Mental Hospital, West Nusa Tenggara, who met the inclusion but not exclusion criteria. The clinical and demographic characteristics data collected in this study were age, gender, type of seizure, etiology, length of education, duration of treatment, and antiepileptic drugs (AED). Cognitive function evaluation has been done by using the CDT instrument. Analysis of the effect of the beginning of seizure on CDT score was carried out by observing the influence of the clinical and demographic characteristics data.

Results: There was a significant difference between the onset of seizure on CDT score $(\mathrm{p}<0.05)$. There were significant differences in aetiology and age in both groups of onsets of the seizure $(p<0.05)$, but not in the characteristics of gender, type of seizure, level of education, duration of treatment and AED in both groups of onsets of the seizure $(p>0.05)$.

Conclusion: The onset of the seizure in epilepsy patients affect CDT score. This effect might be attributed to etiology and age of epilepsy patients.

Latar Belakang: Epilepsi merupakan salah satu penyebab terjadinya gangguan fungsi kognitif yang berpengaruh terhadap kualitas hidup pasien. Salah satu faktor risiko utama penyebab gangguan fungsi kognitif tersebut adalah onset bangkitan pertama kali. Oleh karena itu, deteksi gangguan fungsi kognitif pada pasien epilepsi penting untuk dilakukan. Clock Drawing test (CDT) merupakan instrumen tervalidasi untuk deteksi gangguan fungsi kognitif pasien epilepsi.

Tujuan: Penelitian ini bertujuan untuk menganalisis pengaruh onset bangkitan pertama kali terhadap skor CDT pada pasien epilepsi.

Metode: Penelitian ini melibatkan 64 subjek penelitian pasien epilepsi di Rumah Sakit Jiwa Mutiara Sukma Provinsi Nusa Tenggara Barat yang memenuhi kriteria inklusi dan tidak memenuhi kriteria eksklusi, dengan menggunakan desain penelitian cross sectional. Data karakteristik klinik dan demografi yang 
dikumpulkan antara lain usia, jenis kelamin, tipe bangkitan, etiologi, pendidikan terakhir, rerata lama pengobatan dan obat antiepilepsi (OAE) yang digunakan. Dilakukan evaluasi fungsi kognitif dengan menggunakan instrumen CDT. Dilakukan analisis pengaruh onset bangkitan pertama kali terhadap skor CDT, dengan memperhatikan pengaruh data karakteristik klinik dan demografi yang lain.

Hasil: Terdapat perbedaan bermakna antara onset bangkitan pertama kali terhadap skor CDT ( $p=0,001)$. Terdapat perbedaan bermakna dalam hal etiologi dan rerata usia pada kedua kelompok onset bangkitan $(p<0,05)$, namun tidak pada jenis kelamin, tipe bangkitan, lama pendidikan, lama pengobatan dan OAE pada kedua kelompok onset bangkitan pertama kali $(p>0,05)$.

Kesimpulan: Onset bangkitan pertama kali pada pasien epilepsi berpengaruh terhadap skor CDT. Pengaruh tersebut dapat merupakan interaksi antara onset bangkitan pertama kali dengan etiologi dan usia pasien epilepsi.

\section{INTRODUCTION}

Around 50 million people in the world are suffered from epilepsy. ${ }^{1}$ There are at least 700.000-1.400.000 cases of epilepsy in Indonesia, where approximately $45-50 \%$ of those cases happen in children. ${ }^{2}$ The total amount of visits regarding epilepsy patients in Mutiara Sukma Mental Hospital, West Nusa Tenggara, in 2016 is $47,6 \%$ of the total out patients with neuronal disease. ${ }^{3}$

Epilepsy is characterised by recurrent seizure with a time difference between two seizures over 24 hours. These seizures might destroy in brain neuron and disturb several brain functions. ${ }^{4}$ Impairment in cognitive function is one of major damage caused by repeated seizures that affect intellectual growth in children, and functional status and life quality in adults. ${ }^{5}$ There are multiple factors concerning the cause of cognitive impairment in epilepsy patients, some of them are type of seizure, a etiology of epilepsy, onset of seizure, frequency and duration of seizure, and treatment of epilepsy. ${ }^{6}$ The onset of seizure is one of the most important and determining factor of cognitive dysfunction. ${ }^{6}$ The emergence of seizure is the age when the first seizure occured. The onset of seizure can be categorized into the development of seizure at $\leq 20$ years old and $>20$ years old. ${ }^{7}$ If the early onset of seizure happens after the age of twenty, it is usually symptomatic epilepsy, and if it happens before reaching twenty, it is ordinarily idiopathic epilepsy. ${ }^{8}$

Deterioration in cognitive function that adversely affects patient's quality of life means that screening and preventing the loss of cognitive function in epilepsy patients is essential. ${ }^{9}$ Evaluation of cognitive function can be done through the neuropsychological test, an example being Clock Drawing Test (CDT), which is a global cognitive impairment screening instrument. The reasons for choosing CDT are based on the simplicity of the examination instrument and short screening duration..$^{10}$ This study aims to investigate the effect of the first onset of seizure towards Clock Drawing Test result on epilepsy patients in Mutiara Sukma Mental Hospital, West Nusa Tenggara.

\section{METHODS}

This study is an observational comparative analytical study with cross-sectional sample data-taking. Data collecting is done using consecutive random non-probability sampling. ${ }^{11}$ The population of this study involved epilepsy patients of Mutiara Sukma Mental Hospital, West Nusa Tenggara. Study inclusion criteria were patients more than 14 years old and willing to participate in the study. Exclusion criteria consisted of illiterate patients, patients with vision impairment or blind, patients with difficulty in hearing, mentally retarded, and patients unwilling to continue their participation in the study. Every epilepsy outpatients who admitted to neurology unit at Mutiara Sukma Mental Hospital, and who also met the criteria of inclusion but not the exclusion criteria, were asked to be subjects of the study. The studier explained about the purpose of the study, procedures, patients' confidentiality, and then studyer did an informed consent. Study data was taken by filling questionnaire about general characteristics, which consist of name, age, gender, length of education, seizure type, etiology 
of epilepsy, the onset of seizure, duration of treatment, and AED consumed. Afterwards, the subject did the aforementioned-and-explained CDT examination, and the data was inputted and analyzed.

Characteristics concerning age were tested using T-uncoupled test. Data about the duration of treatment were examined using Mann-Whitney, while components such as sex, duration of education, type of seizure, etiology of seizure, and AED used were tested using Chisquare to determine their effects on the two onset of seizure groups in affecting the CTD score. Acquired data concerning CDT score and first onsets of seizure would be analyzed through comparative analytic hypothesis test that is Mann-Whitney.

\section{RESULTS}

The total sample involved in this study was 64 . The data of this study are composed of subject's general characteristics that theoretically could affect the cognitive function of epilepsy patients ergo they are crucial to being treated as necessary variables, and there must be individual differences on the two onsets of seizure groups. ${ }^{6,12-14}$ General characteristic data concerning gender, length of education, type of seizure, duration of treatment, and AED did not make significant differences $(\mathrm{p}>0.05)$ while data concerning age and etiology of seizure showed significant differences $(\mathrm{p}<0.05)$.

The mean age in the group of $\leq 20$ years old onset of seizure was $26,20 \pm 9,995$ years and $46,96 \pm 12,038$ in $>20$ years old onset of seizure group. The proportion between of male and female subjects in $\leq 20$ years old onset of seizure group were equal. There were more male subjects than female in $>20$ years old onset of seizure group. Type of seizure between the two groups was dominated by the generalized seizure. Etiology of epilepsy in $\leq 20$ years

Table 1. The general characteristic of study subjects and onset of the seizure.

\begin{tabular}{|c|c|c|c|}
\hline Patient's Characteristic & $\begin{array}{c}\text { Onset }<20 \text { Years old } \\
(n=40)\end{array}$ & $\begin{array}{c}\text { Onset }>20 \text { Years old } \\
(n=24)\end{array}$ & Pvalue \\
\hline Gender & & & 0,331 \\
\hline Female & $20(31,25 \%)$ & $9(14,06 \%)$ & \\
\hline Male & $20(31,25 \%)$ & $15(23,43 \%)$ & \\
\hline Type of seizure & & & 0,843 \\
\hline Partial & $16(25 \%)$ & $9(14,06)$ & \\
\hline General & $24(37,5 \%)$ & $15(24,43 \%)$ & \\
\hline Etiology of seizure & & & $0,017^{*}$ \\
\hline Idiopathic & $34(53,12 \%)$ & $14(21,87 \%)$ & \\
\hline Symptomatic & $6(9,37 \%)$ & $10(15,62 \%)$ & \\
\hline Length of Education & & & 0,511 \\
\hline$<12$ years & $25(39,06 \%)$ & $13(20,31 \%)$ & \\
\hline$>12$ years & $15(23,43 \%)$ & $11(17,18 \%)$ & \\
\hline Age mean, $\mathrm{x} \pm \mathrm{SD}$ (years) & $26,20 \pm 9,995$ & $46,96 \pm 12,038$ & $0,000^{*}$ \\
\hline Duration of treatment mean, $\mathrm{x} \pm \mathrm{SD}$ (month) & $36,00 \pm 98,491$ & $26,67 \pm 77,503$ & 0,051 \\
\hline AED & & & 0,114 \\
\hline Monotherapy & $24(37,5 \%)$ & $20(31,25 \%)$ & \\
\hline Combination & $14(21,87 \%)$ & $4(6,25 \%)$ & \\
\hline CDT score mean, $\mathrm{x} \pm \mathrm{SD}$ & $2,22 \pm 1,121$ & $1,12 \pm 1,116$ & $0,001^{*}$ \\
\hline
\end{tabular}

*Significant P-value $<0,05$ 
old onset of seizure group was prominently idiopathic (53.12\%) rather than symptomatic (9.37\%). Etiology of epilepsy in $>20$ years old onset of seizure group was dominantly idiopathic with the percentage of $21.87 \%$ and symptomatic with $15.62 \%$. Less-than-twelve-years duration dominated lenght of education in both groups. The mean of the period of treatment $\leq 20$ years old onset of seizure group was the $36,00 \pm 98,491$ month, while in $>20$ years old onset of seizure group was the $26,67 \pm 77,503$ month. The AED used was predominantly monotherapy, that was carbamazepin, followed by phenytoin and valproic acid in both emergence of seizure groups.

The result of analysed data on the effect of the first onset of seizure towards CDT score was tested using Mann-Whiteny. There was the significant difference between the onset of the seizure and CDT score $(\mathrm{p}=0,001)$

Table 2. The result of the statistical test of the effect of onset of seizure towards CDT Score.

\begin{tabular}{lcccc}
\hline & $\mathbf{N}$ & $\begin{array}{c}\text { Median } \\
\text { (minimum-maximum) }\end{array}$ & Mean \pm SD & P \\
\hline CDT score on onset $\leq 20$ Years old & $40(66,66 \%)$ & $2,00(0-4)$ & $2,22 \pm 1,121$ & $0,001^{*}$ \\
CDT score on onset $>$ 20 Years old & $24(37,5 \%)$ & $1,00(0-3)$ & $1,12 \pm 1,116$ & $(<0,05)$ \\
\hline *Significant P-value $<0,05$
\end{tabular}

*Significant P-value $<0,05$

\section{DISCUSSION}

After performing statistic test on subject's general characteristics that were suspected to influence cognitive function difference on the two groups, obtained significance value from the age and etiology characteristics shows that there were significant differences on the two onsets of seizure groups which means that age and etiology affect cognitive function differences on the two groups. Meanwhile, gender, type of seizure, duration of treatment, length of education, and AED did not show significant difference value on the two groups, which means that those general characteristics didn't affect the cognitive function difference on the two onset of seizure groups.

The result of this study shows that there are significant differences between onset of seizure towards CDT score $(\mathrm{p}<0,05)$. CDT score means on $\leq 20$ years old onset group was $2,22 \pm 1,121$ while on $>20$ years old onset group was 1,12 $\pm 1,116$. This result showed that CDT score mean of $\leq 20$ years old onset group had higher score rather than the $>20$ years old onset group. It is known that CDT score ranges between $0-4$, where 0 means that subjects didn't do the CDT as instructed and four means that subjects did the CDT perfectly as instructed. Better CDT score in $<20$ years old onset of seizure group than
$>20$ years old onset of seizure group shows that the $\leq 20$ years old onset group underwent worse cognitive function deterioration than $<20$ years old onset group. The onset of the seizure is roughly representing the etiology of epilepsy as well as the prognosis of cognitive impairment which are occurred..$^{15}$ Dominating etiology in $<20$ years old onset group was idiopathic, which was $53.12 \%$, while in $>20$ years old onset group, the seizure etiology between idiopathic and symptomatic were relatively comparable with the percentage of idiopathic being $21.87 \%$ and symptomatic $15.62 \%$. This condition agrees with the bibliography from Price and Wilson which states that the cause $<20$ years old onset is usually idiopathic while $>20$ years old onset is generally symptomatic.

Different etiology of epilepsy interfere with cognitive function. Symptomatic epilepsy with neuronal damage experiences significant cognitive function deterioration, compared to idiopathic epilepsy without brain neuron damage. Results from the previous study showed that patients with general idiopathic undergo a milder decline in cognitive function, compared to patients with symptomatic epilepsy. In children, symptomatic epilepsy has the higher risk to suffer more severe deterioration in cognitive function than idiopathic epilepsy. ${ }^{16-20}$ Previous 
study supports the result of this study that shows that $>20$ years old onset seizure group undergoes more severe cognitive function deterioration than $\leq 20$ years old onset group.

Cognitive decline in epilepsy can be by neuronal damage in seizure focus. That neuronal damage might be compensated by neuroplasticity so that cognitive decline can be minimised. Compensation mechanism of neuroplasticity might repair the neuronal loss in the brain. Therefore deterioration of cognitive function might be resolved. ${ }^{19,21}$ Neuroplasticity is a structural and functional change of brain neuron than can be achieved through experience and practice. These experience and practice change the development of neuron through 3 different ways, that were by influencing gene expression, secreting the neurotrophin, and interfere with the neurotransmitter secretion, such as norepinephrine, that affects normal neuron development. ${ }^{22}$ Basic mechanism of neuroplasticity is neurogenesis (creation of new neuron), sprouting (transferring the function of damaged neuron to another intact neuron), and creation of new synapse. Neuroplasticity works optimally in a critical period in which brain is maturating. The development or maturation of brain happens below the age of 20 or in children period, while neuroplasticity in the adult period is suboptimal in repairing or adapting to neuronal damage. ${ }^{22-25}$ This development can partially explained why neuronal damage in epilepsy patients with onset of seizure before the age of 20 years old can repair itself relatively well rather than those patients after the age of 20 years old.

Meanwhile, neuroplasticity in the epileptic onset of seizure after the age 20 years old might not be as well as in onset of the seizure before the age 20 years old. Dendrites do neuroplasticity in children. Dendrites respond to experience and create new synapses in hours or even minutes after trauma. Developing brains produce excess synapses, in which these synapses play a vital role in the process of learning and memorizing. ${ }^{26}$ In teenagers and adults, there's a decrease in the activity of dendrite proliferation and synapse creation. $^{27}$

During the development of baby and children brains, by using animal's brain model, they are more capable of repairing damage caused by seizure induced by neuron excitation, and they're more capable of adapting to seizures. Age mechanism is responsive to brain neuron's ability in repairing better during a developing period, but its mechanism is not fully known. The mechanism that might explain the better fixing of children's brain neurons is inflammation response, in which inflammation response in children is relatively mild, while in adult's brains there are cytokine secretion and other inflammation mediators from traumatised neuron cells that contribute to cell death. The second mechanism that can explain the phenomenon in which children's neurons fix better is the involvement of mitochondria in children's brains, where mitochondria produce two uncoupled protein which decreases membrane gradient, preventing accumulation of ROS (Reactive Oxygen Species) and preventing seizure-caused cell death. Other factors that also play a role are the high concentration of brain-derived neurotrophic factor (BDNF) and other growth factors that protect neurons from excitatory injury. ${ }^{28}$

Better neuroplasticity mechanism before the age 20 rather than after supports the result of this study and it can explain why there are worse deteriorations in cognitive function in $>20$ years old onset group. The epileptic seizure can damage brain neuron, therefore, causing dysfunction in brain neuron and cause a decline in cognitive function. Brain neuronal damage can be minimized by neuroplasticity mechanism, where this mechanism works optimally before the age 20. This shows that onset of seizure that happens before the age 20 has neuroplasticity mechanism that might minimize neuronal damage so that it doesn't cause massive deterioration in cognitive functions, while onset of seizure after the age 20 might have more prominent decline in cognitive function because of the neuroplasticity mechanism that works less optimally after the period 20 . The theory 
of neuroplasticity compensation mechanism supports the result of this study stating that more deterioration in cognitive function happens in the onset of seizure after the age of 20 when compared to onset of seizure below 20 .

This study had several limitations. By using the cross-sectional design, the analysis of the effect of seizure onset on global cognitive function of each patient within a specified period cannot be done. Ideally, to determine the impact of the onset of seizures on cognitive function, it is necessary to evaluate cognitive function, in this case using CDT instruments in different periods of time. Since etiology of epilepsy and age can theoretically interfere the cognitive function, by using the concept of brain reserve, they should also be taken into account as the factors, other than the onset of the seizure, which can affect cognitive function in this study. Finally, many of the subjects and their relatives could not determine the onset of seizures accurately. Therefore, the onset of the seizure in this study was dichotomized into two groups of age, namely $>20$ years and $<20$ years. The accurate history of onset of seizure might help the researcher to analyse the significance and the strong correlation of length of onset of seizure with CDT score.

\section{CONCLUSION}

In end, the onset of the seizure in epilepsy patients affect CDT score. This effect might be attributed to etiology and age of epilepsy patients. In the future study, it is recommended to conduct th cohort study to assess CDT score at the baseline and after the specific period to evaluate the effect of onset of the seizure to the degree of cognitive decline of opeilepsy patients. Better medical records are needed to help the researchers in tracing the accurate onset of seizure.

\section{CONFLICT OF INTEREST}

We declare that there is no conflict of interest.

\section{Acknowledgement}

Non declare

\section{REFERENCES}

1. WHO. Epilepsy.[Internet]. 2017 [updated 2017 Feb]. Available from: http://www. who.int/mediacentre/factsheets/fs999/ en/

2. Suwarba IGNM. Insidens dan karakteristik klinis epilepsi pada anak. Sari Pediatri. 2011;13(2).

3. Harahap HS, Indrayana Y, Amalia E. Treatment pattern and cognitive function in epilepsy patients in Mutiara Sukma Mental Hospital. Jurnal Kedokteran Brawijaya. 2017;29(4):335-40.

4. Sherwood L.Fisiologi Manusia: Dari sel ke sistem.6thEd.Translated from English by B.U. Pendit.Jakarta: EGC.2011.

5. Lodhi $S$ and Agrawal N.Neurocognitive problems in epilepsy.Advances in Psychiatric Treatment.2012;18(3):232-240.

6. Lopes AF, Simões MR, Monteiro JP, Fonseca MJ, Martins C, Ventosa L, et al. Intellectual functioning in children with epilepsy: Frontal lobe epilepsy, childhood absence epilepsy and benign epilepsy with centro-temporal spikes. Seizure [Internet]. BEA Trading Ltd; 2013;22(10):886-92.

7. Marini C, King MA, Archer JS, Newton MR, Berkovic SF. Idiopathic generalised epilepsy of adult onset: clinical syndromes and genetics. Journal of Neurology, Neurosurgery, and Psychiatry. 2003;74:192-7.

8. Price SA and Wilson LM. Patofisiologi: Konsep klinis proses-proses penyakit. 6th ed. Translated from English by B.U. Pendit et al. Jakarta: EGC. 2005.

9. Greener M. Beyond seizures: Understanding cognitive deficits in epilepsy. Progress in Neurology and Psychiatry. 2013;(June):312.

10. Agrell B, Dehlin O. The clock-drawing test. Age Agein. 1998;27:399-403.

11. Dahlan MS. Besar sampel dan cara pengambilan sampel dalam penelitian kedokteran dan kesehatan. 3rd ed. Jakarta: Salemba Medika. 2013.

12. Jayant R, Aashal S,Yadav PP, Chaudhari M. Impact of anti-epileptic drugs on cognition: A review. International Journal of Basic and Clinical Pharmacology. 2016;5(2):229-34. 
13. Sundariyati IGAH, Ratep N, Westa W. Gambaran faktor-faktor yang mempengaruhi status kognitif pada lansia di wilayah kerja Puskesmas Kubu II. E-Jurnal Medika Udayana. 2015;4(1).

14. Al Rasyid I, Syafrita Y, Sastri S. Hubungan faktor risiko dengan fungsi kognitif pada lanjut usia kecamatan Padang Panjang Timur kota Padang Panjang. Jurnal Kesehatan Andalas. 2017;6(1):49-54.

15. Kim EH, Ko TS. Cognitive impairment in childhood onset epilepsy: Up to date information about its causes. Korean Journal of Pediatrics. 2016;59(4):155-64.

16. Vingerhoets G. Cognitive effects of seizures. Seizure. 2006;15(4):221-6.

17. You SJ. Cognitive function of idiopathic childhood epilepsy. Korean Journal of Pediatrics. 2012;55(5):159-63.

18. Behavior SS, Motamedi G, Meador K. Behavior. Epilepsy and Behavior. 2003;4:S25S38.

19. Carren M, Donaire A, Sa R. Cognitive disorders associated with epilepsy: Diagnosis and treatment. Neurologist. 2008;14(6S):26-34.

20. Koleoso ON and Uwadiae E. Intellectual function among epileptic children: The role of epilepsy related-factors in Nigeria. IOSR-JHSS. 2013; 16(4): 41-6.

21. Aldenkamp A and Bodde N. Behaviour,cognition and epilepsy. Acta Neurologica Scandinavica. 2005; 112: 19-25.

22. Mundkur N. Neuroplasticity in children. Indian Journal of Pediatrics 2005; 72: 855-7.

23. Raymont V, Grafman J, Raymont V and Grafman J. Cognitive neural plasticity during learning and recovery from brain damage. Progress in Brain Study. 2006; 157: 199-205.

24. Johnston MV. Plasticity in the developing brain: Implications for rehabilitation. Developmental Disabilities Research Reviews. 2009; 15(2): 94-101.

25. Budde H, Wegner M, Soya H, Voelcker-rehage $\mathrm{C}$ and Mcmorris T. Neuroscience of exercise : Neuroplasticity and its behavioral consequences. Neural Plasticity. 2016: 3-6.

26. Kolb B and Gibb R. Brain plasticity and be- haviour in the beveloping brain. Journal of the Canadian Academy of Child and Adolescent Psychiatry. 2011; 20(4): 265-76.

27. Kirk V, Fatola C and Gonzalez MR. Systematic seview of mindfulness induced neuroplasticity in adults: Potential areas ofilnterest for the maturing adolescent brain. Journal of Childhood and Developmental Disorders. 2016; 2:1.

28. Baram TZ. The brain, seizures and epilepsy throughout life: Understanding a moving target. Epilepsy currents. 2012; 12(Suppl 3): 7-12. 